\title{
Archaeological Investigations at the Bowles Creek Site (41CE475), Cherokee County, Texas, in Early 2017
}

Timothy K. Perttula

Heritage Research Center, Stephen F. Austin State University

Kevin Stingley

Texas Archeological Stewardship Network, Texas Historical Commission

Mark Walters

Heritage Research Center, Stephen F. Austin State University

Follow this and additional works at: https://scholarworks.sfasu.edu/ita

Part of the American Material Culture Commons, Archaeological Anthropology Commons, Environmental Studies Commons, Other American Studies Commons, Other Arts and Humanities Commons, Other History of Art, Architecture, and Archaeology Commons, and the United States History Commons

Tell us how this article helped you.

This Article is brought to you for free and open access by the Center for Regional Heritage Research at SFA ScholarWorks. It has been accepted for inclusion in Index of Texas Archaeology: Open Access Gray Literature from the Lone Star State by an authorized editor of SFA ScholarWorks. For more information, please contact cdsscholarworks@sfasu.edu. 


\section{Archaeological Investigations at the Bowles Creek Site (41CE475), Cherokee County, Texas, in Early 2017}

\section{Creative Commons License}

\section{(c) (1) (8)}

This work is licensed under a Creative Commons Attribution-NonCommercial 4.0 International License 


\title{
Archaeological Investigations at the Bowles Creek Site (41CE475), Cherokee County, Texas, in Early 2017
}

\author{
Timothy K. Perttula, Kevin Stingley, and Mark Walters
}

The Bowles Creek is a substantial Historic Caddo period Allen phase settlement on a natural rise in the Bowles Creek floodplain in the Neches River basin in East Texas. There have been several rounds of work completed at the site since it was first recorded by Stingley, including shovel testing, the excavation of 1 x $1 \mathrm{~m}$ units, and the remote sensing of a 2400 square meter area (McKinnon 2017; Perttula and Stingley 2016, 2017; Perttula et al. 2016). In this article, we discuss the archaeological findings from work done at the site in January and February 2017.

\section{Shovel Testing}

Four additional shovel tests (ST 100-103) were excavated at the Bowles Creek site in the southern part of the site, not far north of the current Bowles Creek channel (Figure 1). These shovel tests encountered archaeological deposits in reddish-brown sandy loam sediments from the surface to as deep as $100 \mathrm{~cm}$ bs in ST 103 (Table 1). A feature, perhaps a hearth or pit oven, was encountered in ST 100 between $60-75 \mathrm{~cm}$ bs; the feature fill is a thick ash deposit.

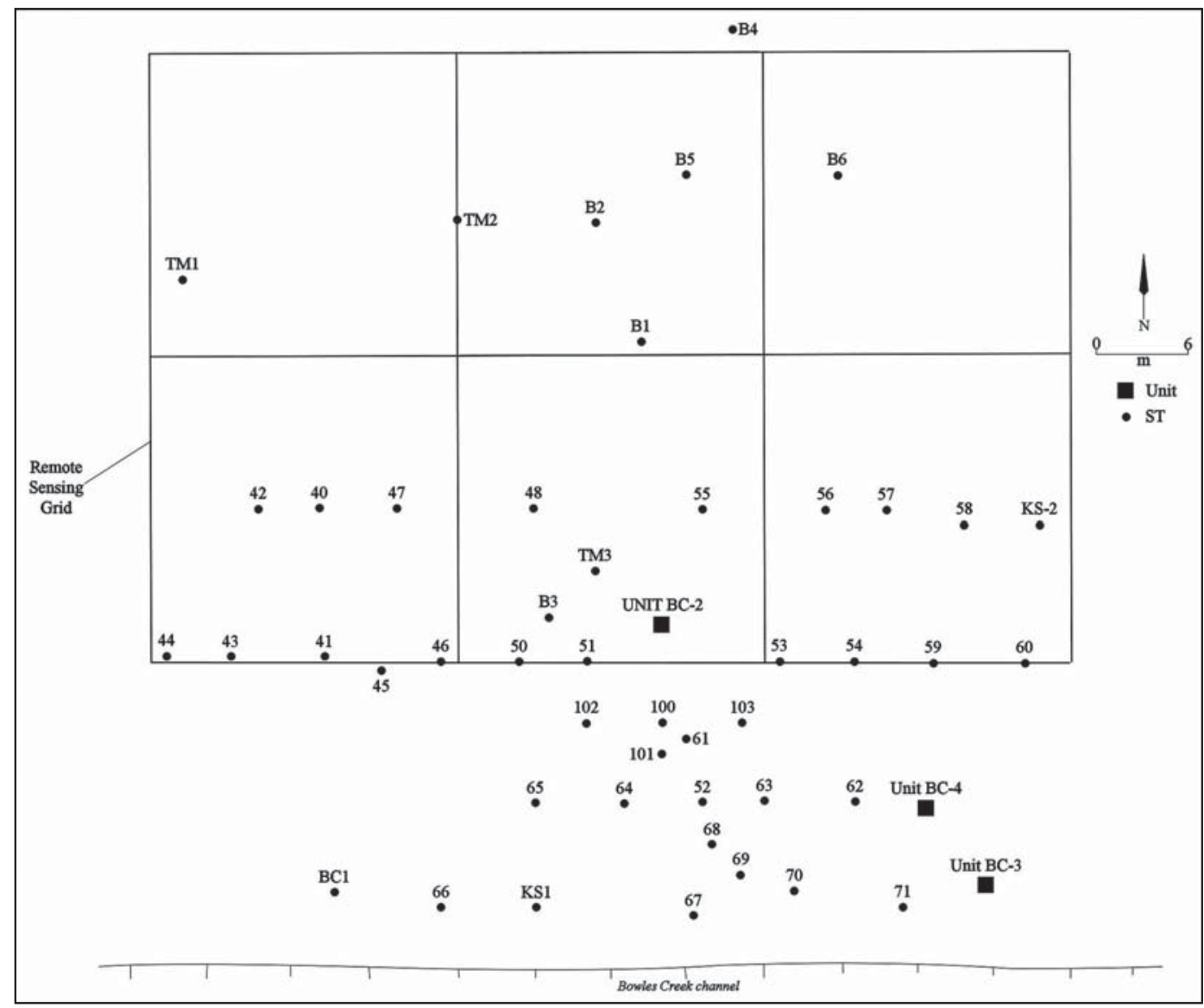

Figure 1. Location of ST 100-103 and BC-3 and BC-4 (1 x 1 m units) at the Bowles Creek site. 
Table 1. Shovel test descriptions.

\begin{tabular}{ll}
\hline ST No. & Description of sediments and depth of artifacts \\
\hline 100 & $\begin{array}{l}0-60 \mathrm{~cm}, \text { reddish-brown sandy loam; } 60-75 \mathrm{~cm} \text {, ash deposit; } 75 \mathrm{~cm}+\text {, red clay; } \\
\text { artifacts from } 0-60 \mathrm{~cm}\end{array}$ \\
$0-100 \mathrm{~cm}+$, reddish-brown sandy clay; artifacts from $0-80 \mathrm{~cm}$ \\
101 & $0-86 \mathrm{~cm}$, reddish-brown sandy loam; $86 \mathrm{~cm}+$, red clay; artifacts from $0-80 \mathrm{~cm}$ \\
102 & $0-100 \mathrm{~cm}+$, reddish-brown sandy loam; artifacts from $0-100 \mathrm{~cm}$ \\
\hline
\end{tabular}

A total of 48 artifacts from the ancestral Caddo component at the Bowles Creek site were recovered in ST 100-103 (Table 2). The density of artifacts is 12.0 per positive shovel test or ca. 96 artifacts per square meters. About 77 percent of the artifacts are plain and decorated sherds. The highest densities of artifacts are between $20-80 \mathrm{~cm}$ bs; animal bone is concentrated between $60-80 \mathrm{~cm}$ bs in ST 100 and ST 101.

Table 2. Depth of artifacts in ST 100-103.

\begin{tabular}{lllllll}
\hline Artifact class & $0-20$ & $20-40$ & $\begin{array}{l}40-60 \\
\mathrm{~cm} \text { bs }\end{array}$ & $60-80$ & $80-100$ & $\mathrm{~N}$ \\
\hline Plain sherd & 1 & - & 1 & 1 & 1 & 4 \\
Decorated sherd & 6 & 13 & 10 & 3 & 1 & 33 \\
$\begin{array}{l}\text { Pipe sherd } \\
\text { Lithic debris }\end{array}$ & - & 1 & 1 & - & - & 2 \\
Animal bone & - & - & - & 2 & - & 7 \\
\hline Totals & 7 & 14 & 13 & 12 & 2 & 48 \\
\hline
\end{tabular}

\section{1 x 1 m Unit Excavations}

Two 1 x 1 m units were excavated at the Bowles Creek site in January 2017: BC-3 and BC-4 (see Figure 1). These are situated between 5-10 m from the Bowles Creek channel (see Figure 1).

In Unit BC-3, an organic horizon and plow zone of reddish-brown sandy loam lie between $0-25 \mathrm{~cm}$ bs. From $25-50 \mathrm{~cm}$ is a buried anthropogenic zone with dark brown sandy loam and flecks of charcoal. From $50-83 \mathrm{~cm}$ bs is a reddish-brown sandy loam deposit. This zone overlies a reddish-brown clay B-horizon. No cultural features were noted throughout the unit, or in the floor at $88 \mathrm{~cm}$ bs. Five gallon soil samples were taken for 1/16-inch water screening from levels 1 to $6(0-60 \mathrm{~cm} \mathrm{bs})$ to recover glass beads; no glass beads were recovered in the unit.

Unit BC-4 had reddish-brown sandy loam deposits from 0-80 cm bs. This deposit overlies a red clay B-horizon. Five gallon soil samples were taken for 1/16-inch water screening from levels 1 to $6(0-60 \mathrm{~cm}$ bs) to recover glass beads; no glass beads were recovered in the unit. 
In addition to seven brushed body sherds from Vessel Section 1 from 30-40 cm bs in Unit BC-3, a total of 366 artifacts were recovered in the two units excavated at the Bowles Creek site in January 2017 (Table 3). The density of artifacts is a substantial 183.0 per square meter. The highest densities of artifacts are between $20-60 \mathrm{~cm}$ bs, but artifacts were found to $83 \mathrm{~cm}$ bs.

Table 3. Depth of artifacts in units BC-3 and BC-4.

\begin{tabular}{lllllllllll}
\hline Artifact class & $0-10$ & $10-20$ & $20-30$ & $\begin{array}{l}30-40 \\
\text { cm bs }\end{array}$ & $40-50$ & $50-60$ & $60-70$ & $70-83$ & N \\
\hline Plain sherd & 2 & 7 & 16 & 17 & 9 & 13 & 2 & 4 & 70 \\
Decorated sherd & 2 & 21 & 41 & $67 *$ & 63 & 40 & 26 & 11 & 271 \\
Pipe sherd & - & - & 1 & 1 & 1 & - & - & - & 3 \\
Arrow point & - & - & - & - & - & - & - & 1 & 1 \\
Ground stone & - & - & - & - & 1 & - & - & - & 1 \\
Lithic debris & - & - & 1 & 3 & 2 & - & 4 & 1 & 11 \\
Animal bone & - & - & - & 2 & 5 & - & - & - & 7 \\
Wood charcoal & - & - & - & 2 & - & - & - & - & 2 & \\
\hline Totals & 4 & 28 & 59 & 92 & 81 & 53 & 32 & 17 & 366 \\
\hline
\end{tabular}

*does not include seven body sherds from Vessel 1 section

More than 93 percent of the recovered artifacts are plain and decorated sherds from ceramic vessels. Ceramic pipe sherds account for 0.8 percent of the assemblage in the two units. Two lithic tools were recovered ( 0.5 percent), along with a small amount of lithic debris (3.0 percent), animal bone (1.9 percent), and wood charcoal (0.5 percent (see Table 3$)$.

\section{Material Culture Remains}

\section{Ceramic Vessel Sherds}

The most recent archaeological investigations at the Bowles Creek site recovered 378 ceramic vessel sherds from plain wares, utility wares, and fine wares (Table 4). About 19 percent are plain rim, body, and base sherds, another 8 percent are from engraved or trailed fine ware vessels, and the remaining sherds ( 73 percent) are from utility wares. Utility wares account for approximately 90 percent of the decorated sherds in this assemblage.

Table 4. Ceramic wares and temper use.

\begin{tabular}{lllccc}
\hline Ware & grog & grog-bone & grog-hematite & bone & N \\
\hline Plain & 68 & 4 & - & 1 & 73 \\
Utility & 246 & 23 & 3 & 3 & $275^{*}$ \\
Fine & 28 & 1 & 1 & - & 30 \\
\hline Totals & 342 & 28 & 4 & 4 & 378 \\
\hline
\end{tabular}

*Does not include Vessel 1 section (Unit BC-3, 30-40 cm bs) body sherds ( $\mathrm{n}=7$ ) 
About 90 percent of the sherds are from vessels tempered only with grog, while another 8.4 percent are from vessels tempered with grog as well as hematite or burned bone (see Table 4). The remaining 1.1 percent of the sherds are from bone-tempered vessels. Sherds from vessels with bone temper, whether the only temper or used in combination with grog, are most common in the utility ware (9.5 percent) and plain ware (6.9 percent); only 3.3 percent of the fine ware sherds have bone temper.

Seven body sherds from a vessel section (Vessel 1) were recovered in BC-3 between $30-40 \mathrm{~cm}$ bs. The vessel, a Bullard Brushed jar, is grog-tempered, incompletely oxidized during firing, and has been smoothed on the interior surface; there are fire clouds on the exterior surface. The vessel walls are 9.1 $\mathrm{mm}$ thick. The vessel body walls have horizontal and opposed brushing marks, and these extend to within ca. $3.5 \mathrm{~cm}$ of the base.

The decorative methods and identified distinctive decorative elements (i.e., bracket-shaped excised area) in this vessel assemblage are listed in Table 5 . The one appliqued body sherd ( 0.3 percent of the decorated sherd assemblage) is probably from the body of a La Rue Neck Banded jar (see Suhm and Jelks 1962:Plate 47b). More than 82 percent of the sherds have brushing marks on the rim and the vessel body; these are all from Bullard Brushed jars. The rims on these vessels have horizontal, vertical, and horizontal-diagonal brushing marks.

Table 5. Decorative methods and elements in the 2017 ceramic vessel sherd assemblage from the Bowles Creek site.

Decorative method and elements

Rim

Body

N

\section{Utility Ware}

Appliqued

straight appliqued ridge

\section{Brushed}

horizontal brushed

horizontal-diagonal brushed

opposed brushed

overlapping brushed

parallel brushed

vertical brushed

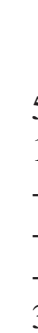

\section{Brushed-Appliqued}

parallel brushed-straight appliqued fillet

parallel brushed-straight appliqued ridge

\section{Brushed-Incised}

incised zone filled with brushed marks

parallel brushed-incised

parallel brushed-opposed overlying incised lines

parallel brushed-overlying parallel incised lines

horizontal incised lines-diagonal opposed brushed

\section{Brushed-Punctated}

parallel brushed-tool punctated rows through the brushing 
Table 5. Decorative methods and elements in the 2017 ceramic vessel sherd assemblage from the Bowles Creek site, cont.

\begin{tabular}{|c|c|c|c|}
\hline Decorative method and elements & Rim & Body & $\mathrm{N}$ \\
\hline \multicolumn{4}{|l|}{ Grooved } \\
\hline parallel grooved lines & - & 1 & 1 \\
\hline straight grooved line & - & 1 & 1 \\
\hline \multicolumn{4}{|l|}{ Incised } \\
\hline parallel incised lines & - & 1 & 1 \\
\hline vertical incised lines & - & 1 & 1 \\
\hline \multicolumn{4}{|l|}{ Pinched } \\
\hline parallel pinched ridges & - & 2 & 2 \\
\hline \multicolumn{4}{|l|}{ Punctated } \\
\hline circular punctated row & - & 1 & 1 \\
\hline free tool punctations & - & 1 & 1 \\
\hline tool punctated rows & 2 & - & 2 \\
\hline
\end{tabular}

\section{Fine Ware}

\section{Engraved}

curvilinear engraved line with tick marks curvilinear excised zone excised bracket el. excised tick mark row horizontal engraved lines with tick marks horizontal-vertical engraved lines parallel engraved lines rectilinear engraved el. straight engraved line straight engraved line with tick marks vertical-diagonal engraved lines with tick marks

\section{Engraved-Brushed}

vertical-diagonal engraved lines; horizontal brushed body

\section{Engraved-Punctated}

horizontal-diagonal engraved lines and excised punctated rows

\begin{tabular}{lll}
- & 1 & 1 \\
- & 1 & 1 \\
- & 1 & 1 \\
- & 3 & 3 \\
1 & 1 & 2 \\
1 & 1 & 2 \\
- & 1 & 1 \\
1 & $3^{*}$ & 4 \\
- & $8^{* *}$ & 8 \\
- & 2 & 2 \\
- & 1 & 1 \\
& & \\
1 & - & 1 \\
& & \\
1 & & \\
& & 3 \\
& & \\
& & \\
\hline & &
\end{tabular}

\section{Trailed}

curvilinear trailed lines

Totals

*one with a white pigment rubbed in the engraved lines

**one with engraved line on the vessel interior 
Another 13 sherds have brushing marks in combination with either appliqued ( 0.7 percent), incised (3.0 percent), or punctated (0.7 percent) elements (see Table 5). The brushed-punctated sherds are also from Bullard Brushed jars (see Suhm and Jelks 1962:21). Six brushed-incised sherds are from Spradley Brushed-Incised vessels. These sherds are from vessels with brushed elements and overlying opposed incised lines cut through the brushing (Figure 2a).

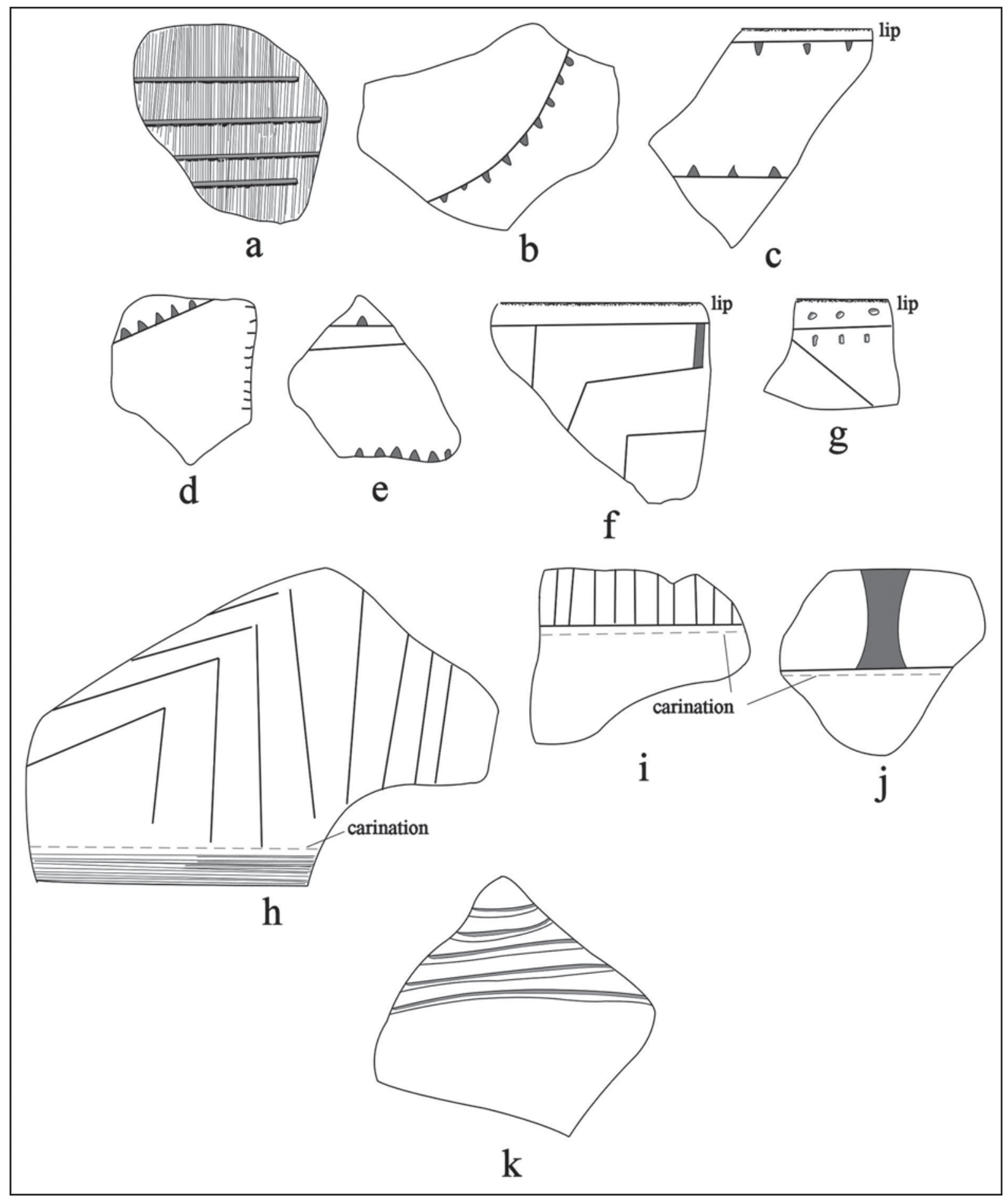

Figure 2. Decorative elements on selected sherds from the Bowles Creek site: a, brushed-incised; b-e, Patton Engraved; f, Mayhew Rectilinear; g, Engraved-excised punctated; h, Ebarb Incised, engraved variety; i, horizontal-vertical engraved; j, Poynor Engraved, var. Hood; k, Keno Trailed. 
Two sherds are from Lindsey Grooved vessels, and two others are from Killough Pinched vessels (see Table 5). A third sherd from Unit BC-3 (20-30 cm bs) may be part of a ring base from a grogtempered Killough Pinched jar (see Suhm and Jelks 1962:Plate 46a-c). The remainder of the utility wares include two incised sherds ( 0.7 percent of the decorated sherd assemblage) that may be from Maydelle Incised vessels and four rim and body sherds (1.3 percent) with either circular or tool punctations.

The principal fine ware at the Bowles Creek site is Patton Engraved ( $n=9$ sherds; see Figure 2b-e) with excised tick marks on the engraved lines. One sherd with a curvilinear engraved line with tick marks (see Figure 2b) or widely-spaced horizontal engraved lines with tick marks (see Figure 2c) may be from Patton Engraved, var. Freeman or var. Fair vessels (see Perttula 2011:Figure 6-66c-d). There is a Patton Engraved, var. unspecified sherd in the assemblage with diagonal and vertical engraved lines with excised tick marks and linear tick marks (see Figure 2d), while another Patton Engraved, var. unspecified sherd has widelyspaced horizontal engraved lines, two of three that have excised tick marks (see Figure 2e).

A rim sherd in the assemblage has horizontal-diagonal engraved lines as well as a row of excised punctations and another row of linear tick marks (see Figure $2 \mathrm{~g}$ ); this sherd may be an unidentified variety of Patton Engraved. Four sherds have rectilinear engraved elements (see Figure 2f), and are from Mayhew Rectilinear vessels (Jackson et al. 2012:178 and Figures 3-58 and 4-8). Sherds of this type have engraved or trailed rectilinear or curved lines; some sherds of the type have tick marks. One engraved-brushed carinated bowl rim and body sherd from the site (see Figure $2 \mathrm{~h}$ ) is identified as an engraved variety of Ebarb Incised (Corbin 2007:15; Gregory and Avery 2007). A principal motif includes a panel of opposed incised or engraved triangles filled with hatched lines pitched in opposite directions (Gregory and Avery 2007:45-47). Another carinated bowl sherd has a horizontal engraved line above the carination as well as a series of closely-spaced vertical engraved lines. The fine ware assemblage also has a carinated bowl sherd from a Poynor Engraved, var. Hood vessel (see Figure 2j; see also Perttula 2011:Figure 6-64e). Three fine ware sherds are from a Keno Trailed vessel with a series of curvilinear trailed lines (see Figure 2k).

\section{Ceramic Pipe Sherds}

There are five elbow pipe sherds in this assemblage from the Bowles Creek site. One (Unit BC-3, $30-40 \mathrm{~cm} \mathrm{bs}$ ) is a grog-tempered pipe bowl rim sherd with a $5.0 \mathrm{~cm}$ orifice diameter. The most distinctive is a grog-tempered Neches variety elbow pipe (cf. Jackson 1933; Perttula 2011:215), pipes with rows of punctations on the stem, heel, and bowl, from ST 103 (20-40 cm bs). This bowl rim sherd has three rows of circular punctations under the lip (Figure 3a). The rim is $4.0 \mathrm{~cm}$ in orifice diameter.

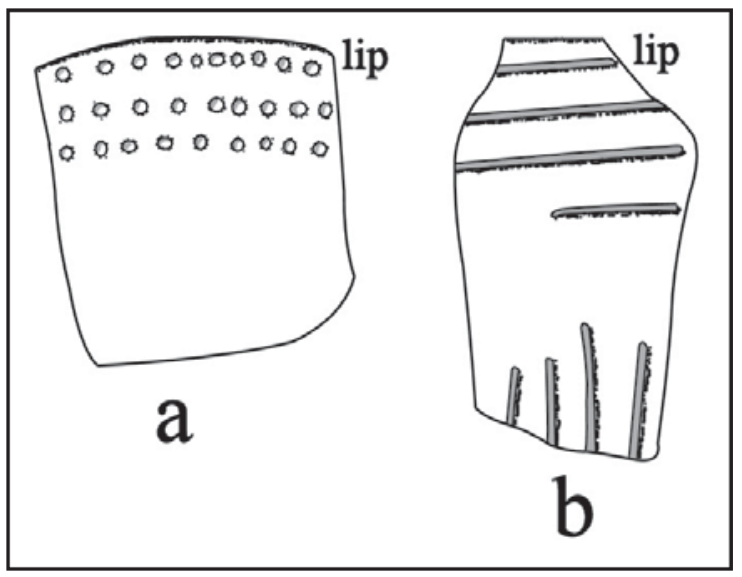

Figure 3. Elbow pipes from the Bowles Creek site: a, Neches pipe, ST 103, 20-40 cm bs; b, incised Var. B elbow pipe stem, Unit BC-3, 20-30 cm bs. 
The third pipe sherd is a grog-tempered stem rim sherd from Unit BC-3 $(20-30 \mathrm{~cm} \mathrm{bs})$ (see Figure $3 b$ ). The stem is $2.0 \mathrm{~cm}$ in diameter and has a flat lip, and has a series of four horizontal incised lines below the lip and a series of four vertical incised lines on the lower part of the stem. This style of pipe has been defined as the Var. B elbow pipe form in the upper Neches River basin (Perttula 2011:Figure 6-23).

A plain grog-tempered elbow pipe bowl sherd was recovered in ST 100, 40-60 cm bs; the sherd has been smoothed on its exterior surface, and is $5.0 \mathrm{~mm}$ thick. Another plain grog-tempered elbow pipe bowl sherd was found in Unit BC-4 between $40-50 \mathrm{~cm}$ bs. This bowl sherd has a $7.0 \mathrm{~cm}$ orifice diameter and is $4.7 \mathrm{~mm}$ thick.

\section{Chipped and Ground Stone Tools}

A unifacial and fragmentary flake arrow point, possibly of the Cuney type, was recovered between $70-83 \mathrm{~cm}$ bs in Unit BC-3. It is made from a local petrified wood. The point fragment is corner notched with a small downward-pointing barb, and a concave base. The point is $2.8 \mathrm{~cm}$ in length, $1.4 \mathrm{~cm}$ in width, and only $0.2 \mathrm{~cm}$ in thickness.

The one ground stone tool is a mano fragment in Unit BC-4, $40-50 \mathrm{~cm}$ bs, made from Catahoula Sandstone; it has been ground smooth on two sides. The fragment is $2.5 \mathrm{~cm}$ in length, $1.3 \mathrm{~cm}$ in width, and $0.8 \mathrm{~cm}$ in thickness.

\section{Lithic Debris}

Lithic debris occurs in low densities in the Bowles Creek archaeological deposits. Only 13 pieces of lithic debris were recovered in ST 100-103 and Units BC-3 and BC-4 (see Tables 2 and 3). About 77 percent of the lithic debris is petrified wood; 20 percent of these pieces have cortical remnants (Table 6), and the raw material was probably gathered in local stream gravels. Almost 8 percent of the lithic debris is on quartzite, another local lithic raw material.

Table 6. Lithic debris in the Bowles Creek site artifact assemblage.

\begin{tabular}{lccc}
\hline Raw Material & Cortical piece & Non-cortical piece & N \\
\hline Petrified wood & 2 & 8 & 10 \\
Quartzite & - & 1 & 1 \\
Light gray chert & - & 1 & 1 \\
Dark gray chert & 1 & - & 1 \\
\hline Totals & 3 & 10 & 13 \\
\hline
\end{tabular}

The remainder of the lithic debris are cherts (see Table 6). The light and dark gray cherts are not locally available in this part of the Neches River basin, and they may have come from cobbles or pebbles whose ultimate sources were in the Edwards Formation in Central Texas. 


\section{Animal Bone and Wood Charcoal}

Only a small amount of animal bone $(n=14)$, burned and unburned, and wood charcoal $(n=2)$ was recovered in the latest investigations at the Bowles Creek site. These remains have not yet been analyzed.

\section{Summary and Conclusions}

Limited shovel testing and the excavation of $21 \times 1 \mathrm{~m}$ units were completed at the Bowles Creek site (41CE475) in January and February 2017, mainly to clarify the extent and character of the Historic Caddo period Allen phase deposits found there. One shovel test encountered a feature marked by a thick ash lens from $60-75 \mathrm{~cm}$ bs, and Unit BC-3 identified a $25 \mathrm{~cm}$ thick buried anthropogenic zone from $25-$ $50 \mathrm{~cm}$ bs that contained a high density of cultural materials.

The work recovered 414 artifacts as well as seven body sherds of a Bullard Brushed jar (Vessel Section 1). The majority of the artifacts are sherds from plain ware, utility ware, and fine ware vessels. Ceramic types identified in the sherds include Bullard Brushed, La Rue Neck Banded, Lindsey Grooved, Killough Pinched, and Spradley Brushed-Incised utility ware types; Lindsey Grooved and Spradley Brushed-Incised vessels are found exclusively in post-A.D. 1680 Allen phase components in the Neches and Angelina River basins in East Texas (see Marceaux 2011). Among the fine wares are sherds from Patton Engraved, Mayhew Rectilinear, Ebarb Incised, engraved variety, Poynor Engraved, var. Hood, and Keno Trailed; Patton Engraved, a post-A.D. 1680 fine ware in the Neches and Angelina River basins, is the principal fine ware at the Bowles Creek site.

The Bowles Creek site is a component of the Historic Caddo Neche cluster of ceramic vessel sherd assemblages; this includes several Allen phase Historic Caddo sites on Bowles Creek and the Neches River (41CE291) as well as one Late Frankston phase (ca. A.D. 1560-1680) investigated component of the George C. Davis site (41CE19) (Fields and Thurmond 1980) on the northern part of the terrace east of the Neches River. These components have high proportions of brushed sherds and ratios of brushed to other wet paste sherds (Perttula 2016: Table 3). These assemblages are almost exclusively comprised of grog-tempered vessels, but differences between the sites in the proportion of bone-tempered vessels (either as the sole temper or in combination with grog) suggest that two contemporaneous groups of Allen phase sites are present in the Neche cluster. These two groups (I and II) also are notably different in brushed to plain sherd ratios; the Bowles Creek site is included in Group II of the Neche cluster because of its higher proportion of bone-tempered sherds (10.5 percent), its P/DR (0.40), and the ratio of brushed to plain sherds (2.07) Table 7).

Table 7. Summary of the ceramic sherd assemblage from the various phases of investigations at the Bowles Creek site (41CE475).

\begin{tabular}{ll} 
Attribute & Bowles Creek \\
\hline No. of sherds & 2081 \\
No. of decorated sherds & 1484 \\
Plain ware & $597(28.6 \%)$ \\
Utility ware & $1352(65.1 \%)$ \\
Fine ware & $132(6.3 \%)$ \\
& \\
P/DR & 0.40 \\
Brushed/Plain Ratio & 2.07 \\
Brushed/OWP Ratio & 7.60
\end{tabular}


Table 7. Summary of the ceramic sherd assemblage from the various phases of investigations at the Bowles Creek site (41CE475), cont.

\begin{tabular}{ll}
\hline Attribute & Bowles Creek Site \\
\hline Grog-tempered & $89.5 \%$ \\
Bone-tempered & $10.5 \%$ \\
& \\
Fine Ware & $119(8.0 \%)$ \\
Engraved & $3(0.2 \%)$ \\
Engraved-brushed & $3(0.2 \%)$ \\
Engraved-punctated & $6(0.4 \%)$ \\
Trailed & \\
& \\
Utility Ware & $1(0.1 \%)$ \\
Appliqued & $1194(80.0 \%)$ \\
Brushed & $3(0.2 \%)$ \\
Brushed-Appliqued & $25(1.7 \%)$ \\
Brushed-Incised & $17(1.1 \%)$ \\
Brushed-Punctated & $9(0.6 \%)$ \\
Grooved & $62(4.2 \%)$ \\
Incised & $4(0.3 \%)$ \\
Incised-Punctated & $4(0.3 \%)$ \\
Neck Banded & $1(0.1 \%)$ \\
Notched & $10(0.7 \%)$ \\
Pinched & $27(1.8 \%)$ \\
Punctated & \\
\hline
\end{tabular}

$\mathrm{P} / \mathrm{DR}=$ plain/decorated sherd ratio; OWP=other wet paste sherds

Other artifacts present in the assemblage from the Bowles Creek site include sherds from several plain and decorated elbow pipes, a unifacially flaked Cuney arrow point, a ground stone tool, and small amounts of lithic debris, burned and unburned animal bone, and two pieces of wood charcoal. No European trade goods have been recovered from the Bowles Creek site during several phases of shovel testing and $1 \times 1 \mathrm{~m}$ unit excavations.

\section{References Cited}

Corbin, J. E.

2007 Cultural Diversity in the Southern Caddo Region. Journal of Northeast Texas Archaeology 26:11-23.

Gregory, H. F. and G. Avery

2007 American Indian Pottery from Historic Period Sites in North Louisiana. Journal of Northeast Texas Archaeology 26:33-76.

Jackson, A. T.

1933 Some Pipes of East Texas. Bulletin of the Texas Archeological and Paleontological Society 5:69-86.

Jackson, M. K., T. Middlebrook, G. Avery, H. Shafer, and B. Meissner

2012 Trade and Cultural Interaction along El Camino Real de los Tejas During the Spanish Colonial and Republic Periods in Nacogdoches County, Texas. 2 Vols. Nine Flags Museum, Nacogdoches.

Marceaux, P. S.

2011 The Archaeology and Ethnohistory of the Hasinai Caddo: Material Culture and the Course of European Contact. Ph.D. dissertation, Department of Anthropology, The University of Texas at Austin. 
McKinnon, D. P.

2017 Report on Magnetic Gradient Survey at Three Caddo Sites in East Texas. Journal of Northeast Texas Archaeology 72:169-175.

Perttula, T. K.

2011 The Ceramic Artifacts from the Lang Pasture Site (41AN38) and the Place of the Site within an Upper Neches River Basin Caddo Ceramic Tradition. In Archeological Investigations at the Lang Pasture Site (41AN38) in the Upper Neches River Basin of East Texas, assembled and edited by T. K. Perttula, D. B. Kelley, and R. A. Ricklis, pp. 145-320. Archeological Studies Program Report No. 129, Texas Department of Transportation, Environmental Affairs Division, Austin.

2016 Utility Ware Ceramic Metrics and Hasinai Caddo Archaeology in East Texas. Journal of Northeast Texas Archaeology 70:61-68.

Perttula, T. K. and K. Stingley

2016 Additional Material Culture Remains from the Bowles Creek Site (41CE475) in Cherokee County, Texas. Journal of Northeast Texas Archaeology 67:7-14.

2017 Continued Shovel Test Investigations at the Historic Caddo Allen Phase Bowles Creek Site (41CE475), Cherokee County, Texas. Journal of Northeast Texas Archaeology 71:105-122.

Perttula, T. K., K. Stingley, and M. Walters

2016 Historic Caddo Archaeological Sites in Cherokee County, Texas. Journal of Northeast Texas Archaeology 65:1-24.

Suhm, D. A. and E. B. Jelks (editors)

1962 Handbook of Texas Archeology: Type Descriptions. Special Publication No. 1, Texas Archeological Society, and Bulletin No. 4, Texas Memorial Museum, Austin. 